\title{
Conflicts in Group Work: Are they all Bad?
}

Mok Soon Sim, Ira Syaqira Sukimin, Nur Sherina Zainal Abidin, Noor Hanim Rahmat, Eugenie Anyau, Susana Bithiah Varma

To Link this Article: http://dx.doi.org/10.6007/IJARBSS/v11-i11/11246

DOI:10.6007/IJARBSS/v11-i11/11246

Received: 07 September 2021, Revised: 11 October 2021, Accepted: 24 October 2021

Published Online: 09 November 2021

In-Text Citation: (Sim et al., 2021)

To Cite this Article: Sim, M. S., Sukimin, I. S., Abidin, N. S. Z., Rahmat, N. H., Anyau, E., \& Varma, S. B. (2021). Conflicts in Group Work: Are they all Bad? International Journal of Academic Research in Business and Social Sciences, 11(11), $331-341$.

\section{Copyright: @ 2021 The Author(s)}

Published by Human Resource Management Academic Research Society (www.hrmars.com)

This article is published under the Creative Commons Attribution (CC BY 4.0) license. Anyone may reproduce, distribute, translate and create derivative works of this article (for both commercial and non-commercial purposes), subject to full attribution to the original publication and authors. The full terms of this license may be seen at: http://creativecommons.org/licences/by/4.0/legalcode

\section{Vol. 11, No. 11, 2021, Pg. $331-341$}

Full Terms \& Conditions of access and use can be found at http://hrmars.com/index.php/pages/detail/publication-ethics 


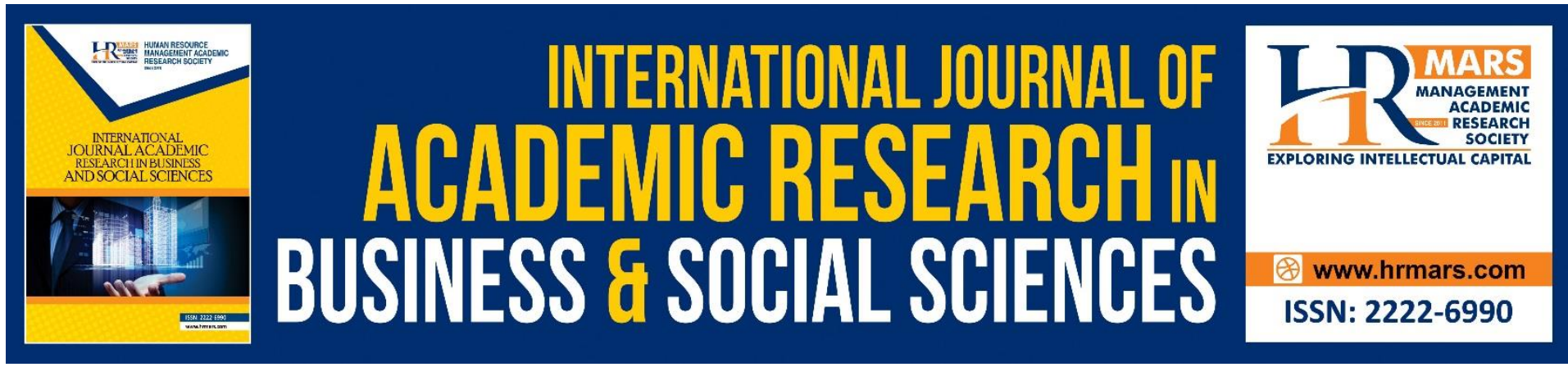

\title{
Conflicts in Group Work : Are they all Bad?
}

\author{
Mok Soon Sim ${ }^{1}$, Ira Syaqira Sukimin², Nur Sherina Zainal \\ Abidin $^{3}$, Noor Hanim Rahmat ${ }^{4}$, Eugenie Anyau ${ }^{5}$, Susana Bithiah \\ Varma ${ }^{6}$ \\ ${ }^{1}$ Akademi Pengajian Bahasa, Universiti Teknologi MARA, Shah Alam, Malaysia, ${ }^{2,3,6}$ Akademi \\ Pengajian Bahasa, Universiti Teknologi MARACawangan Johor, Kampus Segamat, Malaysia \\ ${ }^{4}$ Akademi Pengajian Bahasa, Universiti Teknologi MARA Cawangan Johor, Kampus Pasir \\ Gudang, Malaysia, ${ }^{5}$ Akademi Pengajian Bahasa, Universiti Teknologi MARA Cawangan \\ Selangor, Kampus Dengkil, Malaysia \\ Email:moksoon@uitm.edu.my, irasyaqira@uitm.edu.my,nursherin@uitm.edu.my, \\ noorh763@uitm.edu.my, eugenie@uitm.edu.my, susanavarma@uitm.edu.my
}

\begin{abstract}
Past studies have proven numerous benefits of group work to learners. The benefit go beyond the content of the lesson. A lot can be achieved as a group than individually. Learners gain knowledge as well as communication skills. However, in almost every group discussion, there can be conflicts. Conflicts can occur due to opposing views on the topics or even among personalities. Do learners gain anything from the conflicts? This quantitative study explores the perception of learners on discussion and conflicts during class interactions. 164 students were chosen to respond to a 32 -item questionnaire. The instrument used is a questionnaire of 32 items. Section A is the demographic profile. Section B looks at learners' perception on "competing", section C looks at learners' perceptions on "accommodating", section D looks at learners' perception on "avoiding", while section E looks at learners' perceptions on "compromising and collaborating'. Findings of this study reveal interesting pedagogical implications in the use of class discussions as part of teaching-learning activities.
\end{abstract}

Keywords: Class Discussion, Conflicts, Competing, Accommodating, Avoiding, Compromising, Collaborating

\section{Introduction}

\section{Background of Study}

Group work has been proven to give many benefits to learners. According to Haron \& Rahmat (2020), group work increases the team members self-esteem. The interaction helps members to boost their confidence for future interactions. The communication that took place improves the language and social skills of the members.

\section{Statement of Problem}

Nevertheless, it is undeniable interactions among people of different opinions can sometimes lead to group conflicts. Shonk (2020) identified three types of group conflicts and they are (a) task conflict, (b) relationship conflict and (c) value conflict. Task conflicts refer to 
misunderstandings related to the work assignments. Next, relationship conflicts can stem for difference in personality and/or style of working. Value conflicts can arise because of the differences and values of the team members.

The study by Rahmat, et.al. (2021) found that not all group conflicts are negative. The study also found that when team members defended for their own ideas to be accepted by the group, they are actually sharpening their critical thinking skills. The study further suggested that more group formation and group conflicts research are carried out to explore the dynamics of group conflicts.

\section{Objective and Research Question}

This study is done to explore the strategies learners use to solve conflicts in group work. Specifically, this study is done to answer the following research questions;

(a) How do discussions influence group work?

(b) How do learners compete in group work?

(c) How do learners display accommodation and avoidance in group work?

(d) How do learners compromise and collaborate in class discussions?

\section{Literature Review Interaction among Learners}

Learning takes place not only from what is taught by the teachers or through the activities planned. Learners learn from the interactions with their peers. According to Vygotsky (1978), the social environment can have great influence on the learning process. He suggested that learning takes place through the interactions students have with their peers, teachers, and other experts. Consequently, teachers can create a learning environment that maximizes the learner's ability to interact with each other through discussion, collaboration, and feedback. Vygotsky is also famous for his theory on "zone of proximal development" (figure1). According to this theory, there is a difference between what the learner can do alone than what he can achieve as a group with guidance. The difference between what the learner can achieve with guidance minus what he/she can achieve alone is called the zone of proximal development.

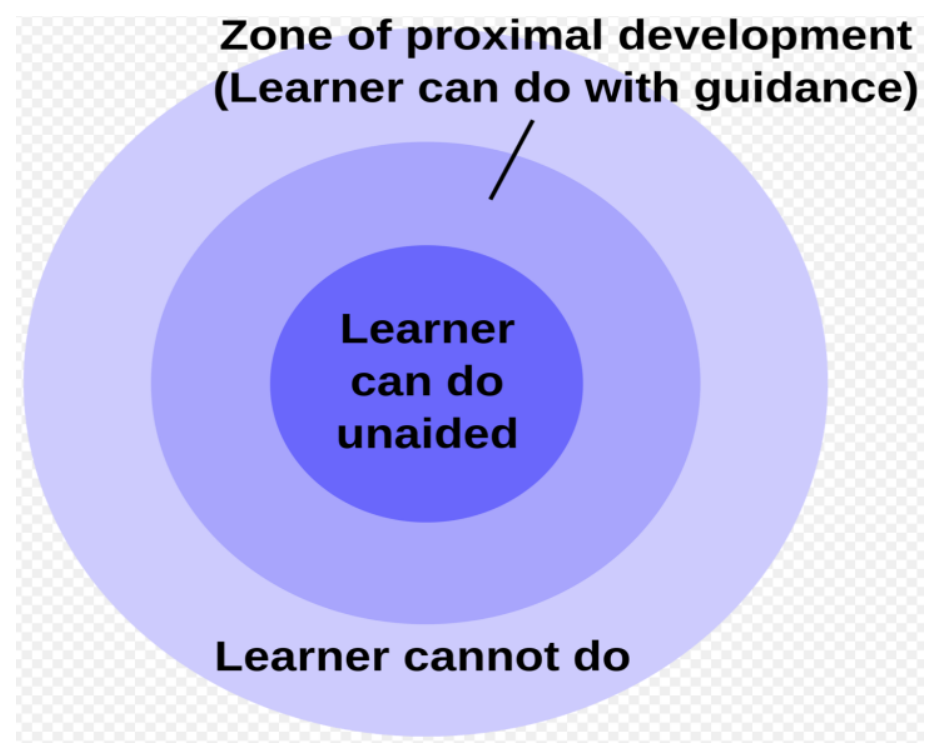

Figure1-Zone of Proximal Development Source: Vygotsky (1978) 
Vygotsky's approach to learners' development is a form of social constructivism, based on the idea that cognitive functions are the products of social interactions. Vygotsky emphasized the collaborative nature of learning by the construction of knowledge through social negotiation. Nevertheless according to Chang \& Kang (2016), sometimes group interaction can be challenging. Learners need to cope with communication, commitment and even responsibility issues among team members.

\section{Resolving Conflicts}

Figure 2 below presents Thomas \& Kilmann's (1974) strategies to resolve conflicts in group work. They presented five strategies learners that learners can use when they try to resolve a conflict in group discussions. The (a) first strategy is "competing". This is when the team member takes a wholly assertive and un-operative approach to resolve the conflict. This could mean standing up for the speakers' right, defending a position, or it could also try to beat the other party. The (b) second strategy is called "accommodating". This is when the team member takes an unassertive and cooperative approach. This might take the form of selfless generosity or another's point of view. The (c) third strategy is "avoiding" this is when the team member takes wholly charity, giving in to another person's orders when he/she would prefer not to, or yielding to an unassertive and uncooperative approach to the conflict and chooses not to deal with the conflict. Avoiding might take the form of diplomatically sidestepping an issue postponing an issue until a better time, or simply withdrawing from a threatening situation.

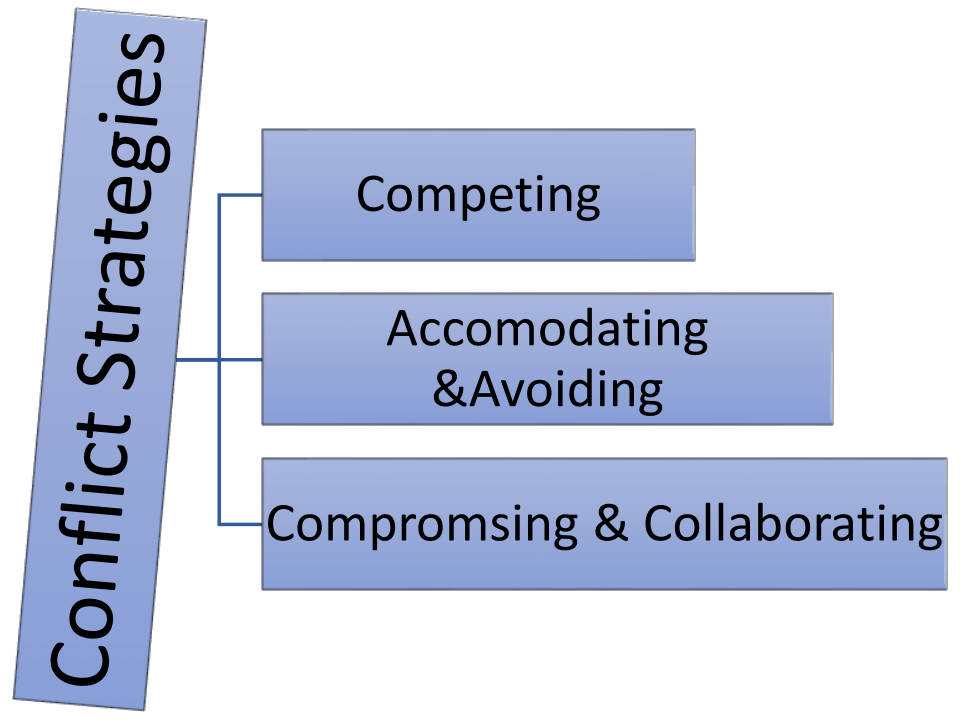

Figure-2-Strategies to Resolve Conflicts Source: Thomas \& Kilmann (1974)

According to Rahmat (2020), the conflicts could be from a total disagreement form that looks like the team members are competing towards something. This disagreement may not be total by the team members. The member in disagreement may decide to accommodate some ideas form the opposing team members. Then the team member with the conflict may decide to avoid more conflicts by assimilating the opposing teams' idea into his/her views. The final stage is the stage where the team members worked on a compromise and make the decision to collaborate as a team. 


\section{Past Studies}

In order to determine the effectiveness of group work, there need to be a form of assessment on its effectiveness. The qualitative study by Chang and Brickman (2008) collected data from in-dept interviews to investigate the perceptions of students about group activities. The study also looked at the strategies used by the learners to interact with their peers. Strategies like assigning roles, group contracts, anonymous peer evaluations, and peer ratings all encourage student participation. Findings revealed that students in both high- and low-performance groups still complained of unequal contributions while praising the social support provided by groups. Students who scored highly on tests were more likely to recognize the benefits of group work, regardless of their groups' overall performance levels, while lower-scoring students perceived group work as time-consuming "busy work" with little cognitive benefit. Next the study by Chang \& Kang (2016), looked into the administrative, logistical and relationship-related challenges in online group work. Challenges in areas such as commitment/responsibility, communication/coordination, structure/management, and leadership are discussed; strategies for how to streamline the management of online group work, how to decrease unnecessary logistical load and extra layers of structure, and how to improve online group work through the design of the syllabus are presented. The study suggests that instructors split group work into individual portions, use peer evaluation, establish guidelines for communication, use tools such as Google Drive to streamline duplicate works, monitor the process of the group work, and give group members freedom, ownership, and autonomy in their group work.

Nevertheless, sometimes group work can be challenging. The study by Samat \& Abd Rahman (2019) investigates the perception of pair or group work among a group of Malaysian preuniversity gifted students in Vector Calculus course. The instrument used in the study is an open-ended questionnaire. Findings show that most students view Vector Calculus as a hard course. They perceived group work as good and helpful other than it affects the way they learn. On the other hand, some students had negative view on group work because of reason like difference of opinions, and even communication styles.

Next, the study by Razaei (2018) was done to investigate what makes group work to be successful. The researcher asked the faculty (instructors and learners) why they gave group work assignments to their students and what their opinions about the best practices in creating effective group work environment for their students are. Results showed that both instructors and learners put importance on communication as an important factor to group work success. The study also discovered that some challenges in group work are shyness, bad chemistry, conflict schedule, poor communication, unprepared drags group and distractions.

Another study was done by Hassanien (2006) to explore the feelings and experience of students regarding group work and group assessment in Higher Education (HE). The study is exploratory and descriptive based on both quantitative and qualitative approach. Findings showed that the students felt that group work is a method that significantly fosters the development of a wider breadth of knowledge through discussion, clarification of ideas, and evaluation of others' ideas. On the other hand, students considered "poor communication" and "poor attendance at group meetings" as the main challenges they face when working within a group 


\section{Conceptual Framework}

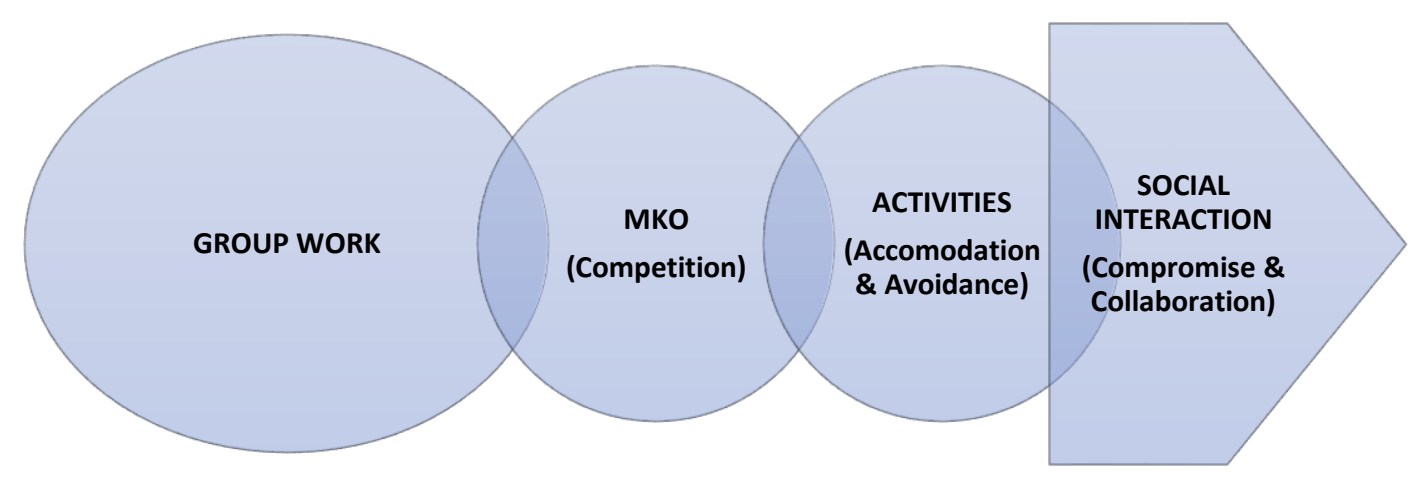

Figure 3- Conceptual Framework of the Study 1

Exploring Conflicts in Group Work

Figure 3 above presents the conceptual framework of the study. The framework is rooted from the theories zone of proximal development (Vygotsky, 1978) and strategies to resolve conflicts by Thomas \& Kilmann (1974). Group conflicts can be resolved with; (a) the presence of someone with the knowledge and skills to guide the learner. It can also be resolved through (b) supportive activities, known as scaffolding, provided by the expert that help guide the learner. Finally, it can be resolved through (c) social interactions that allow the learner to work on their skills and abilities.

\section{Methodology}

This study employs a quantitative design. A survey was given to 164 respondents to investigate how conflicts are resolved in group work. Respondents were chosen from a public university who signed up for a language proficiency course. The course content focus on class discussions in groups. The instrument used is a questionnaire of 32 items. Section $A$ is the demographic profile. Section B looks at learners' perception on "competing", section C looks at learners' perceptions on "accommodating", section D looks at learners' perception on "avoiding", while section E looks at learners' perceptions on "compromising and collaborating'. An analysis of the instrument revealed a score of 0.799 (Table 1) thus showing high level of internal consistency.

Table 1-Reliability Statistics

\begin{tabular}{lll}
\hline $\begin{array}{l}\text { Cronbach's } \\
\text { Alpha }\end{array}$ & \multicolumn{2}{l}{ Cronbach's Alpha } \\
on Standardized Items & N of Items \\
\hline .799 & .852 & 32
\end{tabular}

The questionnaire is converted to google form and respondents answered the link given at the end of the semester after learners have completed their class discussion. Data collected is analysed using SPSS to reveal mean scores and independent t-test scores.

\section{Findings}

Introduction

This section presents the findings according to the research questions presented below. Mean scores are used to present the findings for perception of students towards class discussions 
and conflict resolution. The presentation begins with findings for perception of class discussion among learners. Next, the presentation of findings for conflict resolution is subdivided into perception (i) on competition, (ii) accommodation, (iii) avoidance, and (iv) compromise and collaborate. Finally, the presentation of findings focusses on finding out if there are any significant differences for class discussions and conflict resolution.

\section{Class Discussion during Group Work}

This section reports findings for research question 1;

How do discussions influence group work?

\subsection{5}

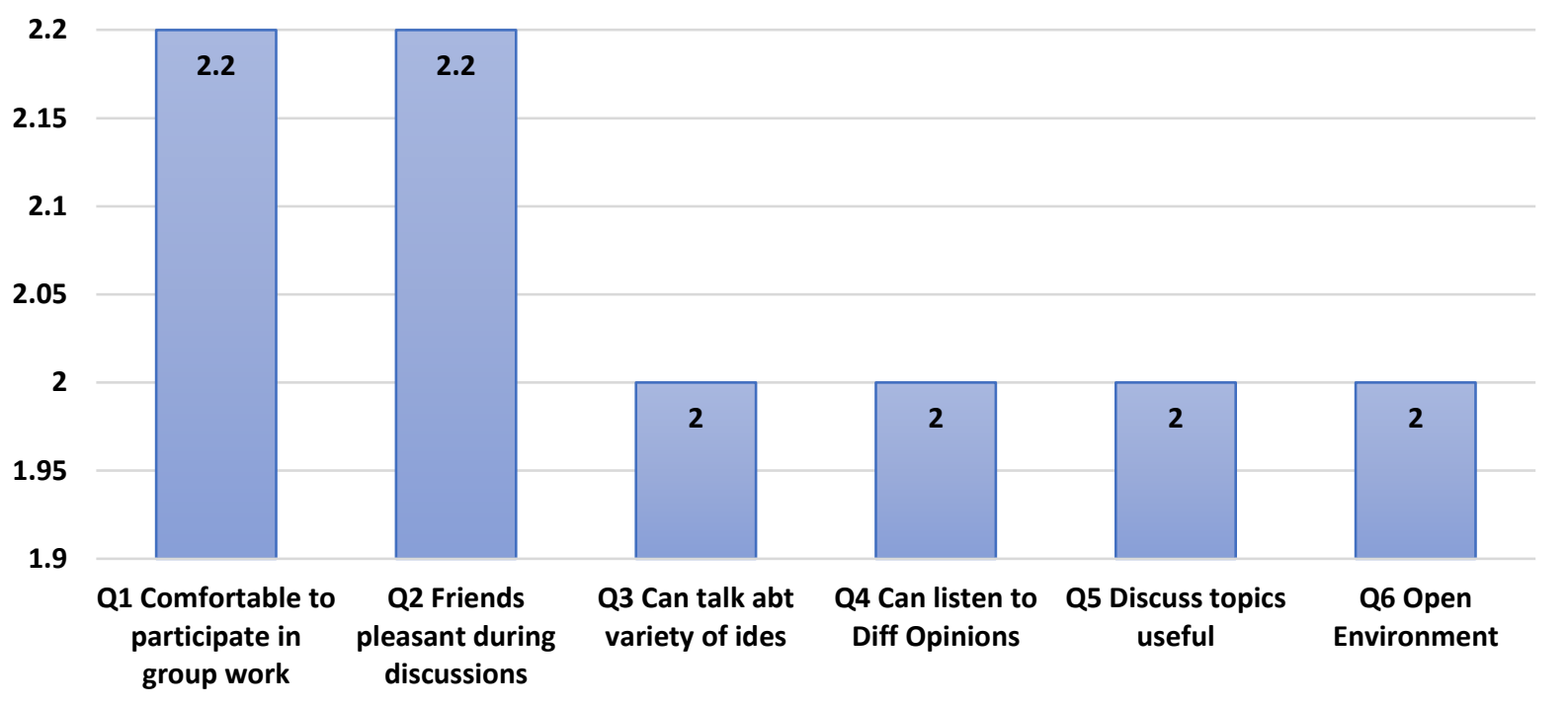

Figure 4- Mean Score for Class Discussions

Figure 4 shows the mean scores for group discussion overall. Generally, learners felt very comfortable participating in class discussions (2.2). Interestingly, they were not very positive towards listening to different opinions on a topic- Q4 -(2) in a group discussion. Low mean scores were also reported for Q3, Q5 and Q6. 


\section{Competing}

This section reports findings for research question 2;

How do learners compete in group work?

3

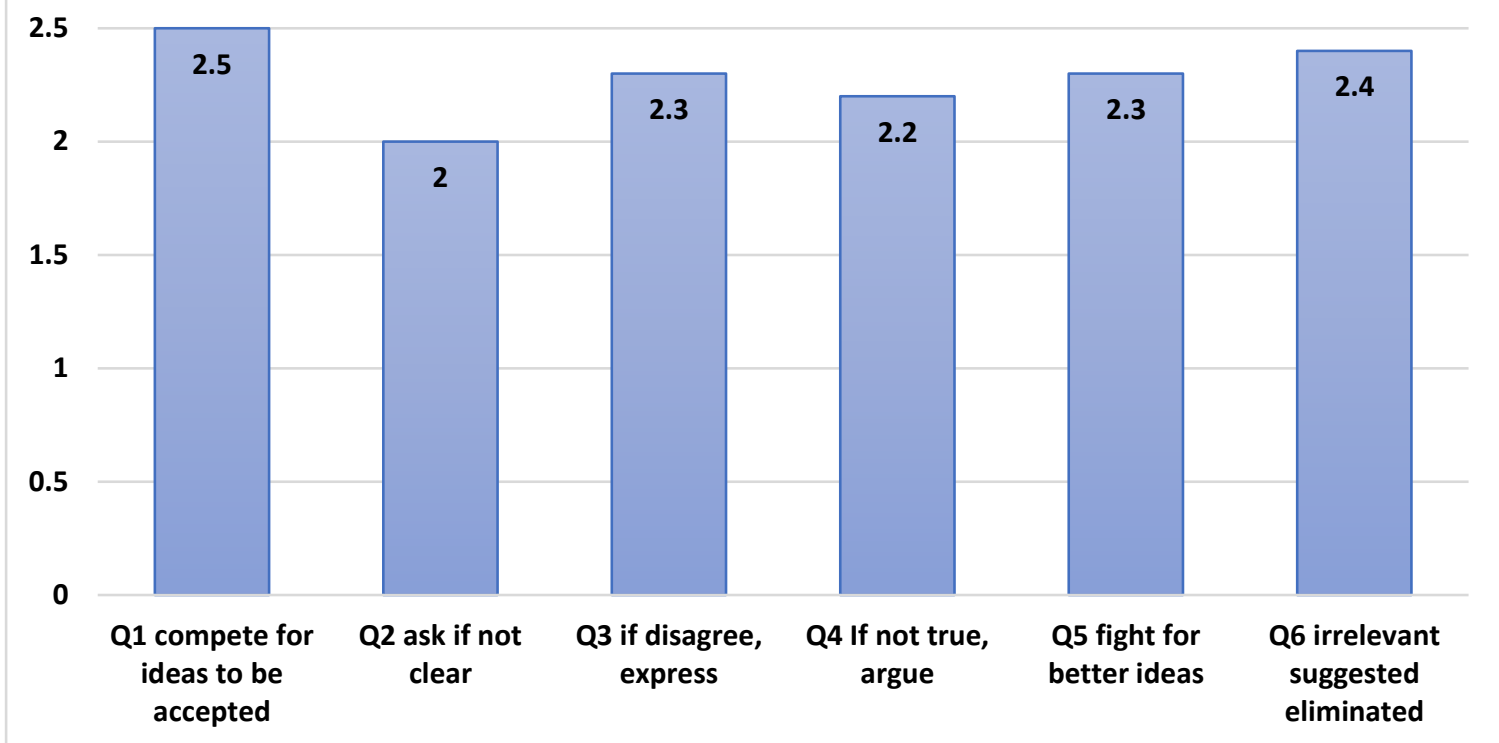

Figure 5-Mean for Competing

Figure 5 shows the mean scores for "competing". The highest mean reported is when learners felt they were "able to compete for" (2.5) for their ideas to be accepted in the group. Interestingly, the second highest mean is when learners fought for "irrelevant suggestions to be eliminated" (2.4). This "competing" mode is seen when learners use argumentative and persuasive skills to compete with a team member whose ideas they wanted to eliminate. 


\section{Accommodating and Avoiding}

This section reports findings for research question 3;

How do learners display accommodations and avoidance in group work?

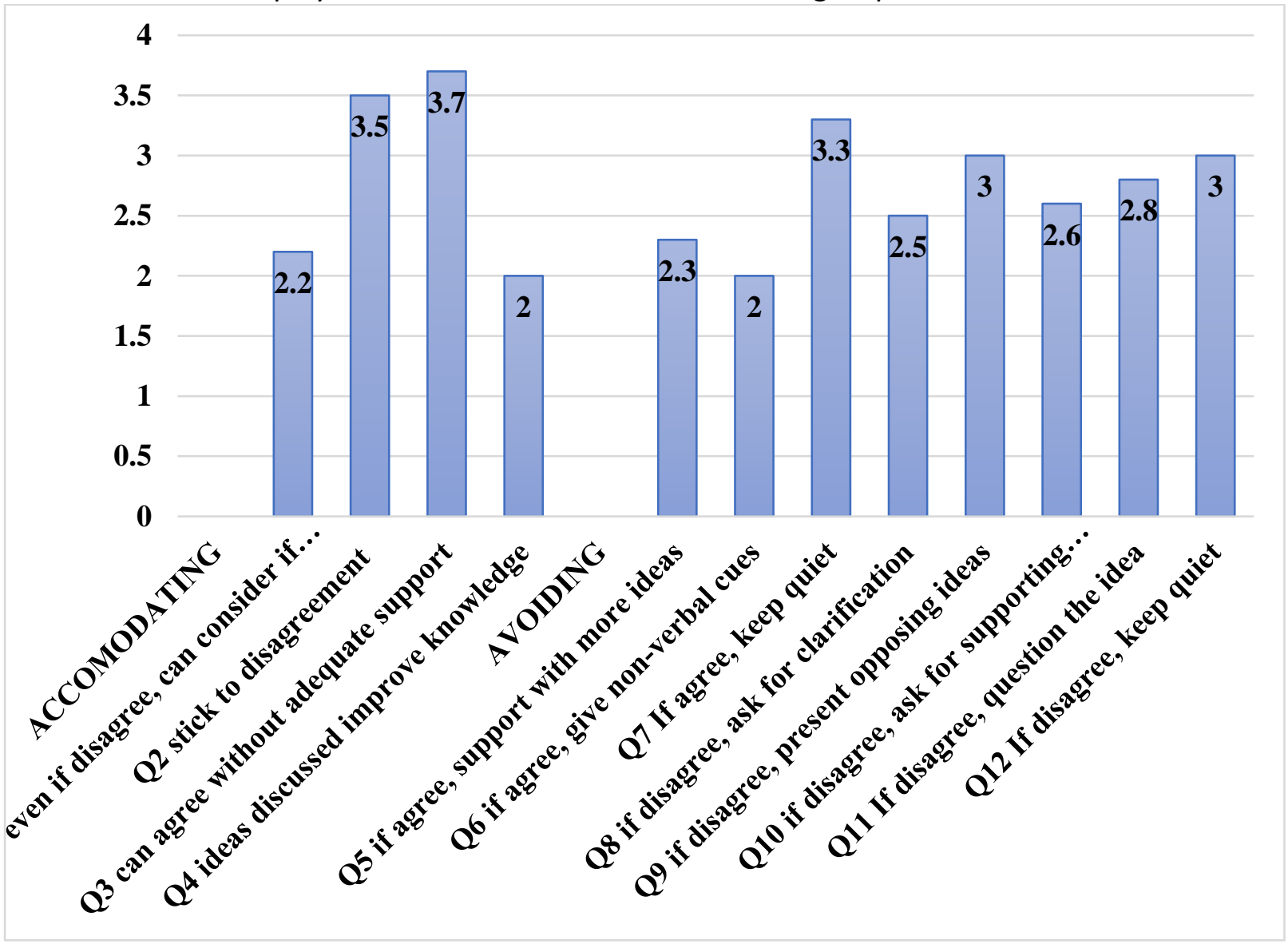

Figure 6- Mean Score for Accommodating and Avoiding

With reference to Figure 6, the mean scores for "accommodating" is presented in 4 items (Q1-Q4). Interestingly, the highest mean score is for "agree with the idea even without adequate support" (3.65). Sometimes team members attempt to "avoid" disagreement to new ideas by agreeing without reservation. The mean for "avoiding" is presented in Q5-Q12. Results indicated the high mean score for "keeping quiet to show agreement" (3.3) and also "keeping quiet for disagreement" (3). 


\section{Compromising and Collaborating}

This section reports findings for the research question 4;

How do learners compromise and collaborate in class discussions?

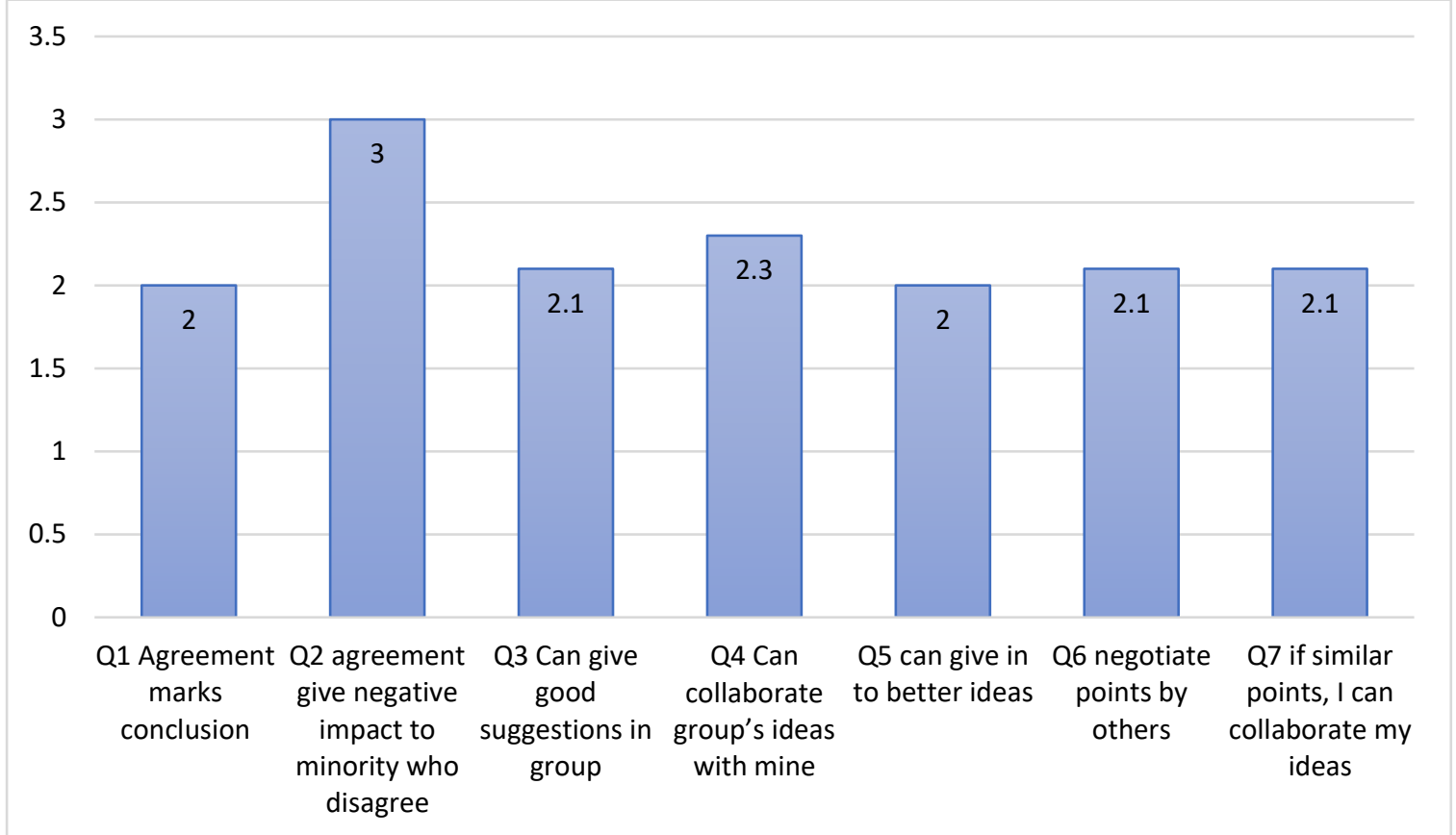

Figure 7-Mean Score for "Compromising and Collaborating"

Figure 7 presents the findings for "Compromising and Collaborating" in terms of mean scores. The highest mean (3) is for "expressing agreement shows the discussion has met with its conclusion." This somewhat shows the willingness of the team to compromise to a conclusion. The lowest mean (2) is for "ability to give in if group members have better ideas". This shows that they are not willing to give in if one member has a better idea.

\section{Conclusion}

\section{Summary of Findings}

Findings in this study revealed that conflicts in group discussions occur when team members cannot talk about different ideas, or even listen to different opinions. This is also supported by Hassanien (2006) who also felt that "poor communication" and "poor attendance at group meetings" as the main challenges they face when working within a group. This is also agreed by Samat \& Abd Rahman (2019) who said that differences in opinion can be challenging in group discussions.

Nevertheless, team members were reported to choose to be quiet if they agree or disagree. They depended on non-verbal communication to show disagreement to avoid misunderstanding. When the team manages to collaborate for better ideas, their work performance improves. This is also agreed by Chang and Brickman (2008) who reported on the benefits that group work can provide toward increasing the quality of work of the group.

\section{Pedagogical Implications}

Conflicts are unavoidable in group work. Instead of looking for ways to avoid conflict or improving interaction; measures can be taken for teachers to actually teach agreement, 
disagreement skills as part of course. Students could also be taught problem solving skills in which these skills can be applied to solve group conflicts when they occur. It is suggested that future research investigate in depth what goes on in group work. In depth studies could be done to analyse the conversations during group work.

\section{References}

Chang, B., \& Kang, H. (2016) Challenges Facing Group Work Online. Distance Education, Vol37(1), pp 73-88. Retrieved from https://eric.ed.gov/?id=EJ1100764

Chang, Y., \& Brickman, P. (2008) When Group Work doesn't Work: Insights from Students. CBE Life Science Education, Vol 17(3) Pp 1-17 Retrieved from https://www.ncbi.nlm.nih.gov/pmc/articles/PMC6234829/

Hassanien, A. (2006) Student Experience of Group Work and Group Assessment in Higher Education, Journal of Teaching in Travel \& Tourism, 6:1, 17-39, Retrieved from https://doi.org/10.1300/J172v06n01_02

Haron, H., \& Rahmat, N. H. (2020) Exploring the Theory of Activity in English language Writing: The Case for Whatsapp. International Journal of Asian Social Science, Vol 10(11), pp. 671-684. Retrieved from https://doi.dx/10.18488/journal.1.2020.1011.671.684

Rahmat, N. H., Aripin, N., Razlan, Z., Arepin, M., Mohandas, E. S., \& Mok, S. S. (2021) Analysing the Cadence of Group Conflicts across Gender during Online Learning. European Journal of Open Education and E-Learning Studies, Vol 6(2), pp 55-69. Retrieved from https://oapub.org/edu/index.php/ejoe/article/view/3886

Rahmat, N. H. (2020) Conflict Resolution Strategies in Class Discussions. International Journal of Education, Vol 12(3),pp 49-66. Retrieved from https://doi.org/10.5296/ije.v12i3.16914

Thomas, K. W., \& Kilmann, R. H. (1974) The Thomas-Kilmann Conflict Mode Instrument. Mountain View, CA: CPP, Inc. Retrieved from https://doi.org/10.1037/t02326-00

Razaei, A. R. (2018) Effective Groupwork Strategies: Faculty and Students' Perspectives. Journal of Education and Learning, Vol 7(5), pp 1-10. Retrieved from https://doi.org/10.5539/jel.v7n5p1

Samat, F., \& Abd Rahman, N. N. (2019) The Perceptions of Group Work among Malaysian PreUniversity Gifted Students. Journal of Social Sciences and Humanities, Vol 16(5), pp 17. Retrieved from https://e journal.ukm.my

Shonk, K. (2020). 3 Types of Group Conflicts and How to Address them. Harvard law School program on negotiation. Retrieved from http://www.pom.harvard.edu/daily/conflcitresolution/types-conflict/

Thomas, K. W., \& Kilmann, R. H. (1974) The Thomas-Kilman Conflict Mode Instrument. Mountain View, CA: CPP, Inc. Retrieved from https://doi.org/10.1037/t02326-000

Vygotsky, L. S. (1978) Mind in Society: The development of higher psychological processes. Cambridge, MA: Harvard University Press. 